\title{
The coffee leaf miner, Leucoptera coffeella (Lepidoptera: Lyonetiidae): identification of the larval instars and description of male and female genitalia
}

\author{
Isabela O. Motta ${ }^{1 *}$ (D), Juliana Dantas ${ }^{1}$, Leonardo Vidal' ${ }^{1}$, João Bílio ${ }^{1}$ (D), \\ José Roberto Pujol-Luz ${ }^{2}$, Érika V. S. Albuquerque ${ }^{1}$ (D)
}

${ }^{1}$ Embrapa Recursos Genéticos e Biotecnologia, Brasília, DF, Brasil.

${ }^{2}$ Universidade de Brasília, Departamento de Zoologia, Brasília, DF, Brasil.

\section{A R T I C L E I N F O}

Article history:

Received 10 December 2020

Accepted 26 July 2021

Available online 27 August 2021

Associate Editor: Adeney Bueno

\section{Keywords:}

Adult genital tract

Larvae cephalic capsule width

Morphology

Taxonomy

\begin{abstract}
A B S T R A C T
The coffee leaf miner Leucoptera coffeella (Guérin-Mèneville \& Perrottet) is a key pest in coffee producing countries. During their development, the larvae feed on the palisade parenchyma of the leaves, forming mines and necrotic areas. As a result, the photosynthetic area of the plant decreases, affecting coffee production. Despite the severity of the damage caused by coffee leaf miner (CLM), morphological aspects of the larval development and the adult genitalia remain unknown. This work presents the first morphological description of the four larval instars and the adult genitalia of $L$. coffeella. In each larval instar, we measured the Mean $\pm S D(\mathrm{~mm})$ of the cephalic capsules $\left(1^{\text {st }} 0,14 \pm 0,03 ; 2^{\text {nd }} 0,25 \pm 0,04 ; 3^{\text {rd }} 0,32 \pm 0,03 ; 4^{\text {th }} 0,42 \pm 0,03\right)$ and observed the following morphological details: primary setae, prolegs, crochets and ecdysial line of the cephalic capsule. In the adults, we show how to differentiate adult sexing and observed the sexual structures present in both genitalia: male - bulbus ejaculatorius, valva, gnathos and aedeagus, and female - ovipositor, sclerite and corpus bursae.
\end{abstract}

\section{Introduction}

Annually, more than 160 million coffee bags are consumed on all continents (Conselho Nacional do Café, 2019). Coffee is produced in the countries of the neotropical region in America, where the coffee leaf miner Leucoptera coffeella (Guérin-Méneville \& Perrottet, 1842) occurs (Mey, 1994; Pereira et al., 2007). Even though Brazil is the world's largest coffee producer, the coffee leaf miner (CLM) is a key pest causing damages every year (Medina Filho et al., 1977; Vieira et al., 2006; Consórcio de Pesquisa do Café, 2020). The CLM infestation impacts severely the coffee yield and bean quality in all Brazilian producing regions (Parra et al., 1981; Pantoja-Gomez et al., 2019) (Figure 1).

The CLM is a monophagous pest (Reis and Souza, 1986) which feeds exclusively on coffee leaves, seriously compromising the health of the plant. L. coffeella has been reported as responsible for losses that can reach up to $87 \%$ drop in productivity (Neves, 2006). Depending on the season, the defoliation of the coffee plant can reach up to 75\% (Reis and Souza, 1996; Neves, 2006).

The life cycle of $L$. coffeella is holometabolic, including the stages of egg, larva, pupa, and adult in its winged version (Box, 1923) (Figure 2).

\footnotetext{
* Corresponding author.

E-mail: isabela.motta94@gmail.com (I.O. Motta).
}

After being described by Guérin-Mèneville and Perrottet in 1842, the immature forms were only described in 1923 by Harold Box. The larval phase penetrates the palisade parenchyma of the leaves and feeds there forming mines, which gives rise to the common name of this pest. The lesions caused by the mines cause necrosis, thus reducing the photosynthetic area, which can cause severe defoliation in more sensitive coffee genotypes, such as Coffea arabica (Medina Filho et al., 1977; Ramiro et al., 2004). The symptoms of this pest attack consist of mines that progress from light green to brown, as the larva develops and moves to new feeding sites.

The knowledge of life cycle phases is critical to allow the development of pest control methodologies, e.g., oviposition assays, infestation challenge to test pesticide products or resistant cultivars. Studies aimed at chemical control, biological control, transcriptome, and plant resistance to Lepidoptera species pests reported the use of specific larval instars. Wheatley and Crowe (1964) conducted a study to control of mining larvae, Leucoptera meyrickiGhesquiere, 1940, in the field with the application of insecticides sprayed on mined leaves in order to kill larvae of the $2^{\text {nd }}, 3^{\text {rd }}$ and $4^{\text {th }}$ instar, decreasing the development of the infestation. Fragoso et al. (2002) conducted a study, in the laboratory, with the use of organophosphate insecticides in larvae of the 3rd instar 
of $L$. coffeella. Biological control agents of mining larvae have been studied by Draganova and Tomov (1998), in which the fungus species Beauveria bassiana (Bals.) Vuill., is a pathogen of last instar larvae of the species Leucoptera malifoliella (Costa, 1836). Camargo et al. (2015) conducted a transcriptome study with the larval stages of the tomato leaf miner Tuta absoluta (Meyrick, 1917). Perthuis et al. (2005) tested the resistance of transformed $C$. canephora 126 using fourth instar larvae of CLM and Meriño-Cabrera et al. (2018) conducted a study with plant defense as an alternative to control CLM, using larvae of the fourth instar.

Adult sexing is used in experiments aimed at the mortality rate of females and males, laboratory rearing, sexual behavior, and pheromone employment. Information about the male and female mortality rate of L. coffeella was observed by Notley (1948). Katiyar and Ferrer (1968) conducted a study with CLM adult rearing techniques, presenting a cage model and suggesting feeding to keep specimens in laboratory conditions. The sexual behavior of CLM adults has been described in

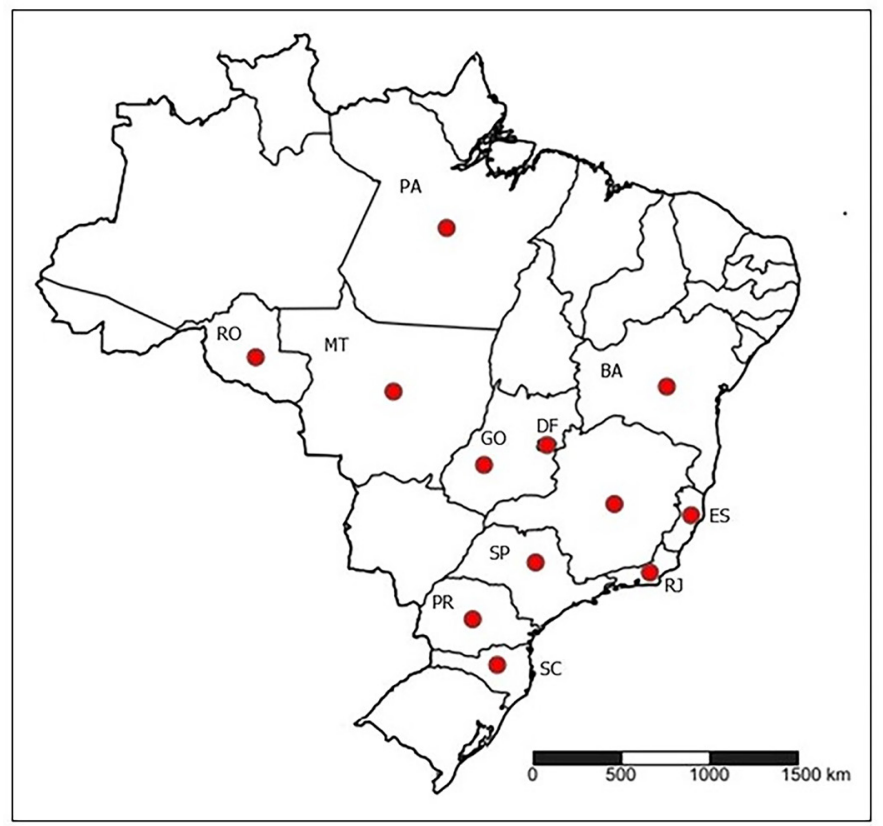

Figure 1 States of Brazil with the incidence of Leucoptera coffeella (red dots). Rondônia (RO), Mato Grosso (MT), Pará (PA), Goiás (GO), Distrito Federal (DF), Bahia (BA), Minas Gerais (MG), Espírito Santo (ES), São Paulo (SP), Rio de Janeiro (RJ), Paraná (PR), Santa Catarina (SC).
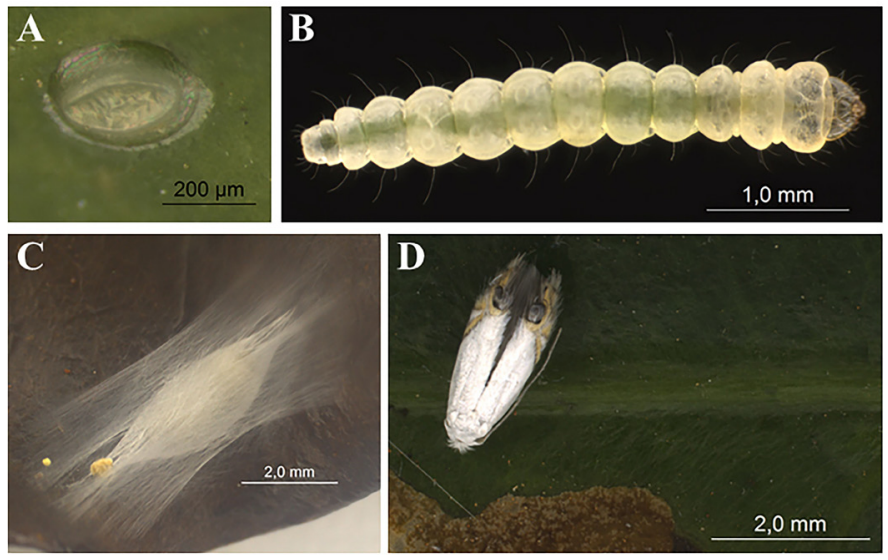

Figure 2 Leucoptera coffeella life cycle phases. (A) Egg Stage. (B) Larval stage. (C) Pupa stage. (D) Adult. detail by Michereff et al. (2007). Malo et al. (2009) conducted a study on the chemical composition of pheromones released by females of L. coffeella. Although the sexual dimorphism in adults of $L$. coffeella is mentioned in the literature (Parra, 1985), there is no information available about the male and female genitalia of this species or the external aspects to differentiate them.

Despite the economic importance and geographical scope of the CLM, further studies on the larval morphological characteristics and sexual dimorphism of $L$. coffeella are lacking. In this work, we present a detailed study on the morphology of larvae for the identification of the four larval instars and description of male and female genitalia of L. coffeella.

\section{Material and methods}

Obtaining insects and rearing: $L$. coffeella collections were carried out at Embrapa Cerrados (Federal District, Brazil, 15³6'15.1" S, 47²'44.4" W) and Embrapa Genetic Resources \& Biotechnology (Federal District, Brazil, 1543'52.8 "S, 4754'10.2” W) between May and August 2020. Leaves with mines and pupae were collected directly from the coffee plant or leaves fallen on the ground around the plant. The leaves with larvae and pupae were taken to the laboratory where they were placed in rearing containers until adult emergence. A cotton soaked with a sugary solution of water with industrialized sugar was offered ad libitum for adult feeding.

Larvae: To examine the larvae and determine the number of instars, the infested leaf mines were opened using tweezers and scalpels and observed with a Leica EZ-4 (c) stereomicroscope. Cephalic capsule width and body length measurements were made using a Leica M205C (c) stereomicroscope and processed with the Leica LAS (c) V3.8 to morphometry and image acquisition software. The width of the cephalic capsule and the body length of 50 larvae were measured in each of the four larval instars. Larval morphological characteristics, associated with cephalic capsule measurements, follow Nielsen and Common (1991). To identify morphological characteristics to distinguish the larval stages, we used (1) presence of primary body setae in the first instar, (2) presence or absence of prolegs in the third instar, (3) presence or absence of crochets in the fourth instar, (4) presence or absence of ecdysial line in the frontal suture of the fourth instar. To observe these structures, the cephalic capsules were processed through diaphanization with $10 \% \mathrm{KOH}$ heated for about $2 \mathrm{~min}$, and larvae were processed through diaphanization with $10 \% \mathrm{KOH}$ heated for about 6 minutes and then washed in water. The images were taken with a Leica DM-2000 @ microscope coupled to a photographic camera and analyzed with Leica LAS @ V 3.8 software.

Sexing: To identify the sex of the adults, the specimens were individualized in Eppendorfs and observed in a ventral view, to analyze the last abdominal segment, with Leica EZ4 @ stereomicroscope.

Genitalia: Male and female genitalia were processed through diaphanization of the abdomen with $10 \% \mathrm{KOH}$ heated to $70^{\circ} \mathrm{C}$, for about five minutes. Subsequently, they were washed in water and dissected in 70\% alcohol. The photographs were taken with light microscopy (LM) using a Leica DFC295 camera mounted on a Leica M205C (c) stereomicroscope and Leica DM2000 (C) microscope. The specimens were measured ( $\mathrm{mm}$ ) with the Leica LAS @ V3.8 software. The terminology of Nielsen and Common (1991) was used for the external morphology of the immature; Box (1923) for external adult morphology; Bradley and Carter (1982); Mey (1994) and Solis and Metz (2016) for male genitalia; Schmitt et al. (1996) and Matthews and Miller (2010) for female genitalia.

Map: The incidence map of the coffee leaf mining in Brazil was built using the SimpleMappr @ program. 


\section{Results}

Morphological characteristics and chaetotaxy of the head and thorax were used to identify the four larval instars of $L$. coffeella. Also, we present a detailed study of the genitalia of males and females to better characterize both sexes.

Immature forms: 1st larval instar (Figure 3A, B). Cephalic capsule variation $0,09-0,21 \mathrm{~mm}$ and body length variation $0,43-1,16$ $\mathrm{mm}$. Body with translucent whitish coloration, pale yellow cephalic capsule with a defined chewing mouthpiece type (Figure 3B), primary setae on the side of the body (Figure 4A), and without prolegs. 2nd larval instar (Figure 3C, D). Variation of the cephalic capsule $0,19-0,32 \mathrm{~mm}$ and variation in body length $0,71-1,70 \mathrm{~mm}$. Body with pale yellow coloration, first body segment wider than the cephalic capsule, body setae longer than in the first instar and without prolegs. Mouthpiece with small spines (Figure 4B). 3rd larval instar (Figure 3E, F). Variation of the cephalic capsule $0,27-0,44 \mathrm{~mm}$ and variation in body length $1,39-2,38 \mathrm{~mm}$. Body and cephalic capsule with yellowish coloration, long body setae, presence of prolegs without defined crochets (Figure 4C). 4th larval instar (Figure 3G, H). Cephalic capsule variation $0,35-0,54 \mathrm{~mm}$ and body length variation 2,54-4,71 mm. Yellowish body, prolegs with crochets in the shape of a uniordinal circle (Figure 4D, E), and cephalic capsule with ecdysial line above the adfrontal suture (Figure $4 \mathrm{~F}$ ).

The morphometry of the immature forms was made based on the width of the cephalic capsule. The head grows in geometric progression and the width increases in a constant ratio, showing that there is variation in the size of the head in changing the larval instars as shown
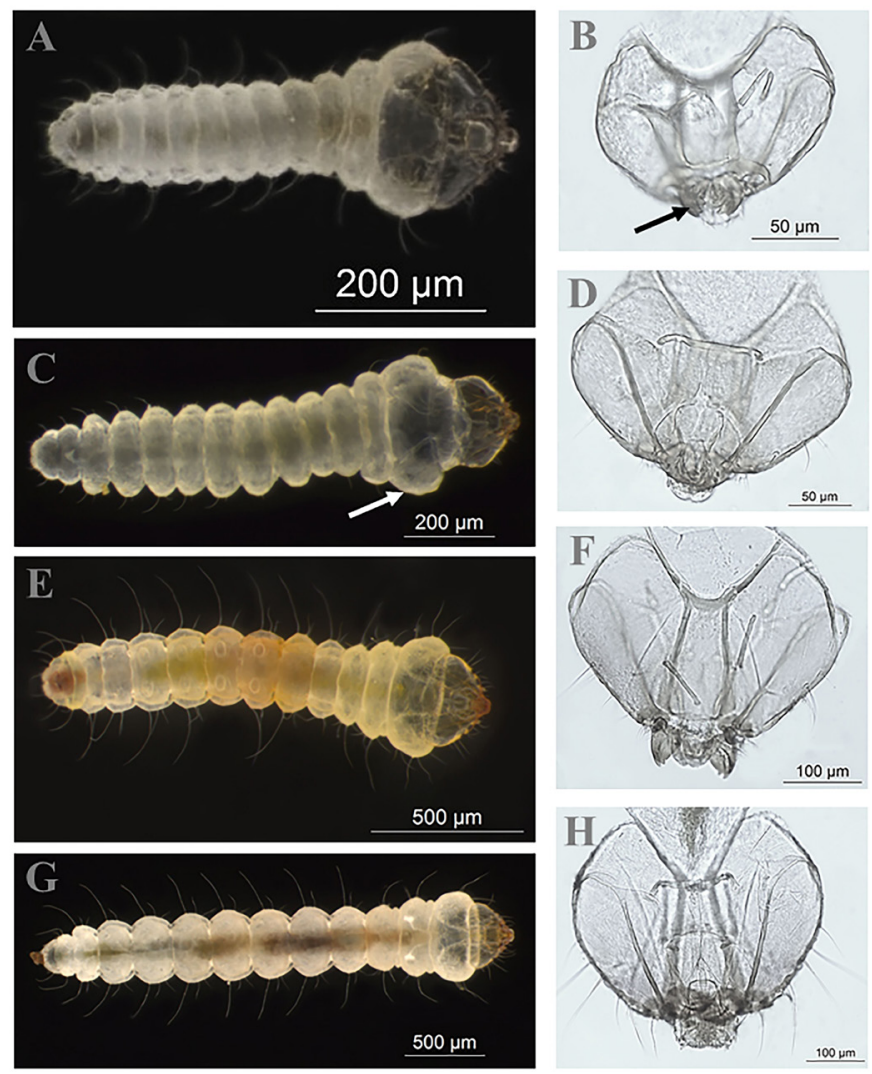

Figure 3 Immatures of Leucoptera coffeella. (A) First instar larva. (B) Cephalic capsule of the first larval instar. Arrow indicates chewing mouthpiece. (C) Larva of the second instar. Arrow indicates first body segment. (D) Cephalic capsule of the second larval instar. (E) Larva of the third instar. (F) Cephalic capsule of the third larval instar. (G) Larva of the fourth instar. $(\mathrm{H})$ Cephalic capsule of the fourth larval instar. by Dyar (1890), Bigger (1969), Ecole et al. (1999), Delbac et al. (2010). The average cephalic capsule width and body length of the different instars are shown in Table 1.

Imago. Male (Figure 5A). Average body length of 1,98 $\pm 0,03 \mathrm{~mm}$. Head. White scales on the dorsal apex. Base of the antenna white, with brownish length. Thorax. Covered with white scales. Legs. Long white scales. Wings. Long and thin, with two rounded black dots surrounded by yellowish scales. Apex of the wings with a row of black scales, and with a "V" shape facing the posterior region of the body (Figure 5B). Abdomen. White colored tergites. In ventral view, the last bipartite segment (Figure 6A). Genitalia. Tergite 8 with coremata, forming a pair of elongated limbs with setae at the apex (Figure 7A). Bilobate sternite 8, with an oval bulbus ejaculatorius (Figure 7A). Bipartite valva, setose, and with small teeth in the internal region of the apex (Figure 7B). Gnathos elongated, forming a thin pair of arms (Figure 7C). Short, cylindrical, and slender aedeagus at the apex (Figure 7D). Female (Figure 8A): Similar to the male except by the average body length of $2,11 \pm 0,10 \mathrm{~mm}$. Apex of the wings with a " $\mathrm{C}$ " shape facing

\section{Table 1}

Mean $( \pm S D)$ of variation in cephalic capsule measurements and body length in the 4 instars of Leucoptera coffeella.

\begin{tabular}{|c|c|c|c|c|c|}
\hline \multirow{2}{*}{$\begin{array}{l}\text { Larval } \\
\text { Instar }\end{array}$} & \multirow{2}{*}{ no. } & \multicolumn{2}{|c|}{ Cephalic capsule width (mm) } & \multicolumn{2}{|c|}{ Body length (mm) } \\
\hline & & Range & Mean \pm SD & Range & Mean \pm SD \\
\hline $1^{\text {st }}$ & 50 & $0,09-0,21$ & $0,14 \pm 0,03$ & $0,43-1,16$ & $0,64 \pm 0,15$ \\
\hline $2^{\text {nd }}$ & 50 & $0,19-0,32$ & $0,25 \pm 0,04$ & $0,71-1,70$ & $1,22 \pm 0,23$ \\
\hline $3^{\text {rd }}$ & 50 & $0,27-0,44$ & $0,32 \pm 0,03$ & $1,39-2,83$ & $2,06 \pm 0,37$ \\
\hline $4^{\text {th }}$ & 50 & $0,35-0,54$ & $0,42 \pm 0,03$ & $2,54-4,71$ & $3,60 \pm 0,63$ \\
\hline
\end{tabular}
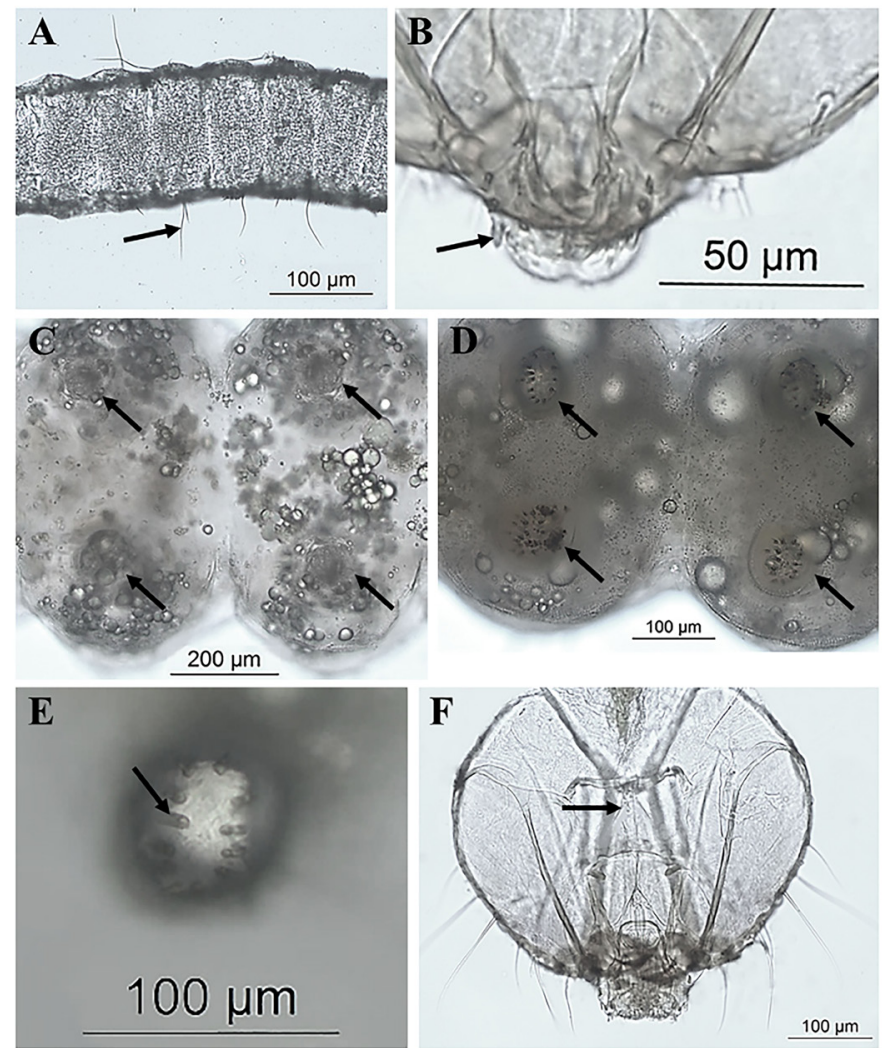

Figure 4 External morphological characteristics of coffee leaf miner Leucoptera coffeella larvae. (A) Dorsal view of the larva body of the first larval instar. Arrow indicates primary seta. (B) Chewing mouthpiece of the second larval instar. Arrow indicates spine. (C) Ventral view of the third larval instar. Arrows indicate prolegs without crochets. (D) Ventral view of the fourth larval instar. Arrows indicate prolegs with crochets. (E) Ventral view of crochets in the shape of uniordinal circle in a fourth instar larva. Arrow indicates crochet. (F) Cephalic capsule of the fourth larval instar. Arrow indicates ecdysial line. 

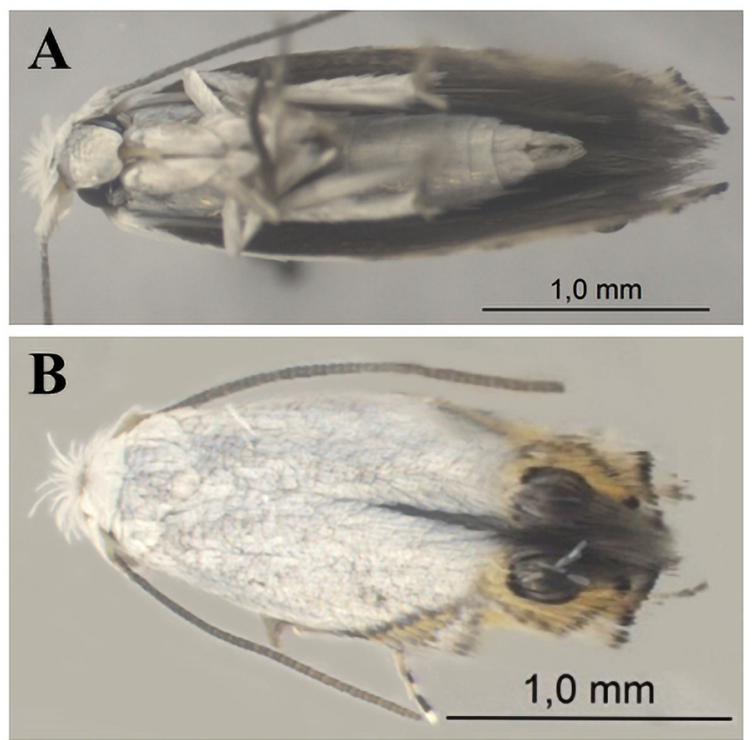

Figure 5 Leucoptera coffeella, adult male. (A) Male ventral view. White-colored body scales. (B) Male dorsal view. Apex of the wings with black dots surrounded by yellow scales, with a "V" shape facing the posterior region of the body.
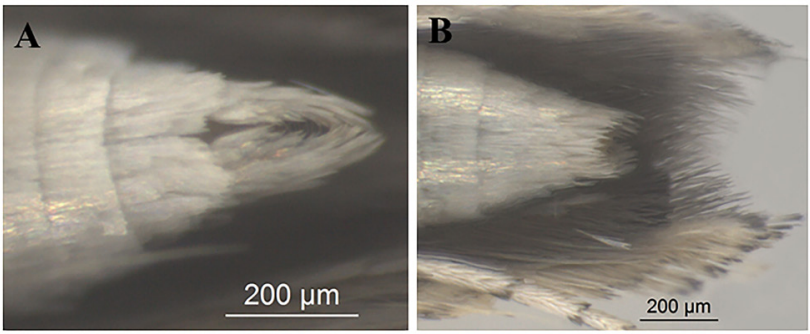

Figure 6 Leucoptera coffeella last abdominal segments. (A) Male last abdominal segment in ventral view, with a white bipartite segment. (B) Female last abdominal segment in ventral view, with a white tubular shape.
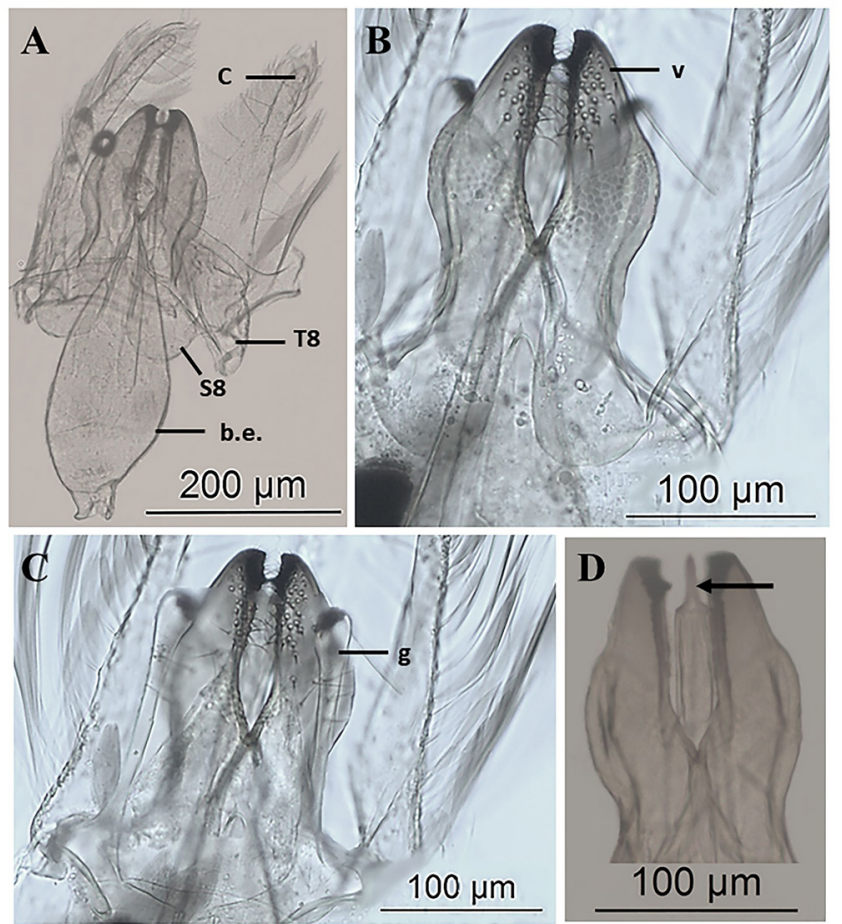

Figure 7 Leucoptera coffeella, male genitalia. (A) Tergite 8, coremata, sternite 8 and ejaculatory bulb ventral view. (B) Valva ventral view. (C) Gnathos ventral view. (D) Aedeagus dorsal view. Arrow indicates apex of aedeagus. $C=$ coremata, $\mathrm{T} 8=$ tergite 8 , $\mathrm{S} 8=$ sternite 8 , b.e. $=$ bulbus ejaculatorius, $\mathrm{v}=$ valva, $\mathrm{g}=$ gnathos . the anterior region of the body (Figure $8 \mathrm{~B}$ ). In ventral view, the last segment of the abdomen with a tubular shape (Figure 6B). Genitalia. Bilobed ovipositor with long apical setae (Figure 9A). Scleritis of the ductus bursae apically tapered and enlarged in the anterior region; extremities of the anterior region are tapered and have a concave shape facing the apex (Figure 9B). Oval membranous corpus bursae with small spines (Figure 9C).

\section{Discussion}

Lyonetiidae is a family of lepidopterans consisting of 204 species distributed in 32 genera (Zhang, 2011). Leucoptera Hübner brings
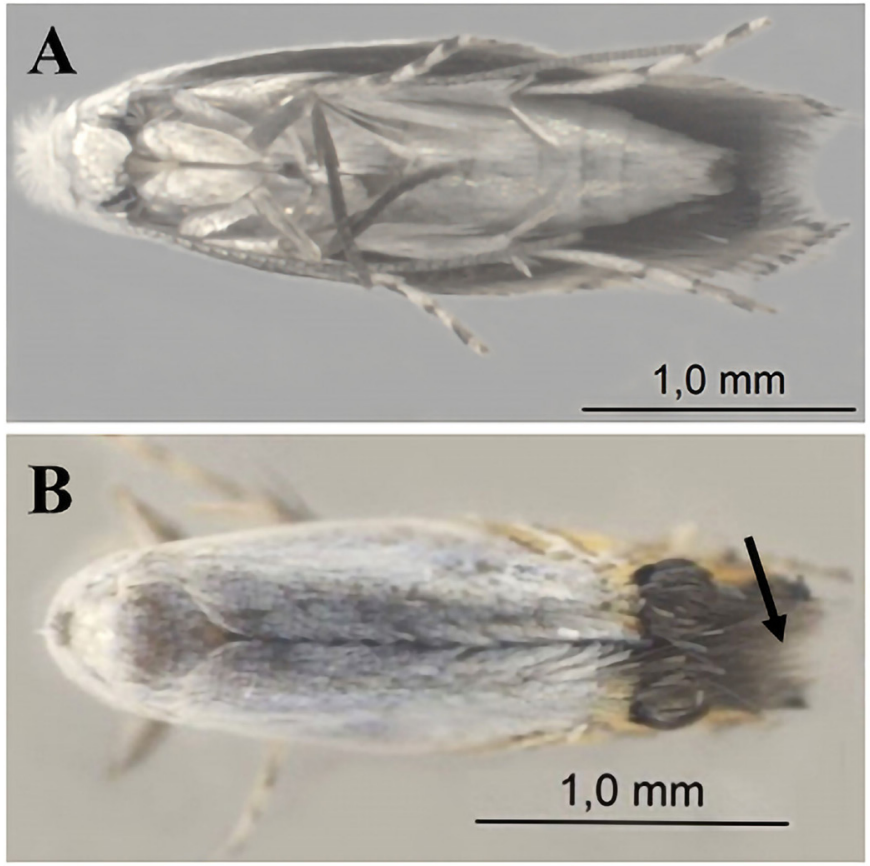

Figure 8 Leucoptera coffeella, adult female. (A) Female ventral view. (B) Female dorsal view. Arrow indicates the apex of the abdomen with a "C" shape facing the anterio region of the body.
A

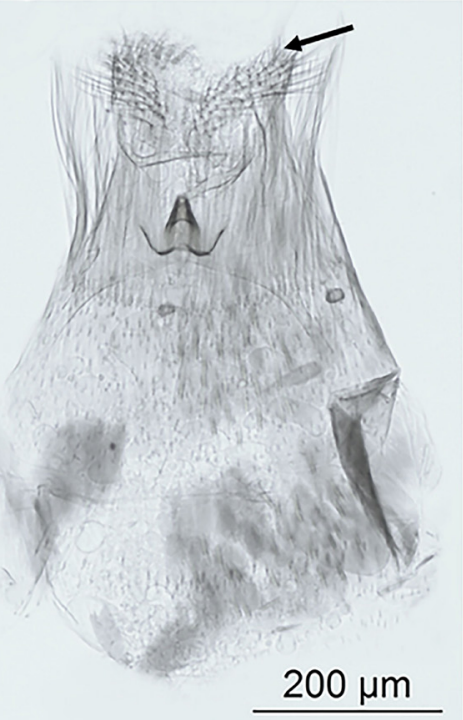

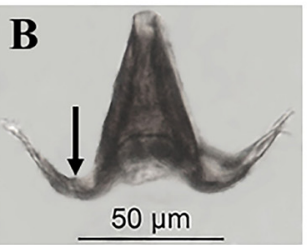

C

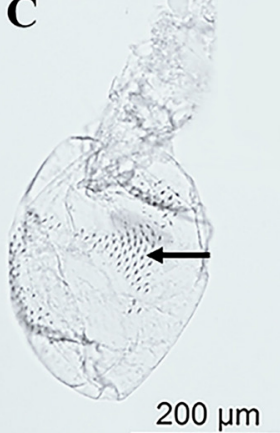

Figure 9 Leucoptera coffeella, female genitalia. (A) Ovipositor ventral view. Arrow indicates ovipositor lobe. (B) Sclerite ventral view. Arrow indicates the sclerite's concave end. (C) Corpus bursae ventral view. Arrow indicates spines. 
together leaf-mining moths that cause economic damage worldwide (Seven, 2006; Magalhães et al., 2010). Although L. coffeella causes serious losses to the coffee crop, knowledge gaps about the biology of the CLM remain to be fulfilled and made publicly available.

The CLM damage causing agents are all the larval stages before pupation (Notley, 1948). Although Notley (1948) declared that L. coffeella has four larval instars, there is no description of the morphological characteristics of each instar. The determination of Lepidoptera larval instars can be done by measuring the cephalic capsule width (Dyar, 1890; Ecole et al., 1999). Besides width of the cephalic capsule, lepidopteran instars may also have different morphological characteristics (Nielsen and Common, 1991). We observed that the $1^{\text {st }}$ larval instar of $L$. coffeella has primary arrows and no prolegs; $2^{\text {nd }}$ instar has no prolegs; $3^{\text {rd }}$ instar presents prolegs without defined crochets; and $4^{\text {th }}$ instar presents prolegs with defined crochets and ecdysial line. The larval instars of $L$. coffeella can be determined by the union of the head capsule measurements and the external body morphological characteristics.

To our understanding, the instar determination by the larval age is less precise than the morphological method we described here. In Navarro-Gutiérrez and Gallardo-Covas (2009), a bioassay study that referred the larval instars according to their age, reported that, in laboratory at $27^{\circ} \mathrm{C}$, the $1^{\text {st }}$ instar correspond to 3 days, $2^{\text {nd }}$ to 7 days, $3^{\text {rd }}$ to 11 days and $4^{\text {th }}$ to 13 days. However, the CLM life cycle is shorter in dry climates combined with higher temperatures (Wolcott, 1947; Dantas et al., 2020). Hence, it is highly probable that a natural variation is reflected in the life cycle timing due to the climatic conditions in the coffee crop (Costa et al., 2012).

The identification of males and females is essential to understand sexual behavior, sex-related mortality rates, and pheromone production (Notley 1948, Katiyar and Ferrer, 1968, Michereff et al., 2007, Malo et al., 2009). Semiochemicals can be used to alter the natural reproductive behavior of insects, decreasing pest population levels (Cardé and Minks, 1995; Dantas et al., 2020). The CLM sexual pheromone was used to determine the pattern of pheromone production by females, as an indirect measure of the behavior calling for sexual intercourse (Lima et al., 2008). However, although several previous studies have used adult sexing, none has clearly explained how to differentiate males from females, so the methodology of sexing males and females has remained unclear.

Alves et al. (2006) presented for the first time the structure of the male reproductive system of $L$. coffeella, but it did not include information regarding the morphology of the male genitalia. Thus, we present here the morphology of the genitalia of males and females of this species, which was not yet known.

The elements in the male and female genitalia of $L$. coffeella corroborating the structures described for the other species of Lyonetiidae (Bradley and Carter, 1982; Mey, 1994). The L. coffeella male exhibits bulbus ejaculatorius and aedeagus. These structures are common with the male genitalia of $L$. malifoliella. In L. coffeella, tergite 8 with setose coremata, bilobed sternite 8 , bipartite and setose valve, and elongated gnathos were observed, forming two thin arms. In contrast, pleurallobus, vinculum, pedunculus, subanalplatte, tuba analis are observed in L. malifoliella and this species does not have a valva (Mey, 1994). In the female genitalia of $L$. coffeella, the structures we observed were bilobed ovipositor, sclerite in a conical shape, and oval corpus bursae with small spines. The corpus bursae was identified by Mey (1994) in the general structure of the Leucoptera female genitalia. The sclerite structure was identified by (Schmitt et al., 1996) in another genus belonging to the Lyonetiidae family, where the female genital structure was characterized by a cruciform "T" shape, while in $L$. coffeella the sclerite has a conical shape.
The characterization of larval instars can be important to identify targets that are more susceptible to efficient and narrow control by natural or synthetic approaches. Equally important is the sexing of the adult in experiments to control CLM, such as the study of control methods based on pheromones. The dissection of adult specimens for genitalia studies confirmed that the sexing method described here by observing external morphology is correctly associated with male or female. These results may support innovative and improved control strategies for CLM Integrated Pest Management (IPM).

\section{Acknowledgements}

The authors are thankful to Adriano Veiga from Embrapa Cerrados for providing access to coffee plantations and for helping with insect sampling. This work was supported by Consórcio Brasileiro de Pesquisa e Desenvolvimento do Café - CBP\&D/Café grant number 10.18.20.004.00.00. The fellowships of Isabela de Oliveira Motta and João Bilio were funded by Fundação de Apoio à Pesquisa - FUNAPE and Leonardo Vidal by Embrapa.

\section{Conflict of interest}

The authors declare that they have no conflict of interest.

\section{Author contribution statement}

Authors JRP and EVSA conceived and supervised the research. Authors IOM, JD, LV and JB conducted the trials.

Authors JD, JRP and EVSA contributed with the biological materials. Authors IOM, JRP and EVSA analyzed data.

Authors IOM, JD, JRP and EVSA wrote the manuscript. Author EVSA secured funding.

\section{References}

Alves, L., Mancini, K., Lino-Neto, J., Dolder, H., 2006. Morphology of the male reproductive system and sperm ultrastructure of Leucoptera coffeella (Lepidoptera: Lyonetiidae): sperm ultrastructure of Leucoptera coffeella. Acta Zool. 87, 131-139. https://doi.org/10.1111/j.14636395.2006.00226.x.

Bigger, M., 1969. Partial resistance of Arabica Coffee to the Coffee Leaf Miner Leucoptera Meyricki Ghesq. (Lepidoptera, Lyonetiidae). East Afr. Agric. For. J. 34, 441-445. https://doi.org/10.1080/00128325.1 969.11662325.

Box, H. E., 1923. The bionomics of the White Coffee-leaf Miner, Leucoptera coffeella, Guér., in Kenya Colony. (Lepidoptera, Lyonetidae.). Bull. Entomol. Res. 14, 133-145. https://doi.org/10.1017/S0007485300056248.

Bradley, J. D., Carter, D. J., 1982. A new lyonetiid moth, a pest of wingedbean. Syst. Entomol. 7, 1-9. https://doi.org/10.1111/j.1365-3113.1982. tb00122.x.

Camargo, R. A., Herai, R. H., Santos, L. N., Bento, F. M. M., Lima, J. E., Marques-Souza, H., Figueira, A., 2015. De novo transcriptome assembly and analysis to identify potential gene targets for RNAi-mediated control of the tomato leafminer (Tuta absoluta). BMC Genomics 16, 635. https://doi.org/10.1186/s12864-015-1841-5.

Cardé, R. T., Minks, A. K., 1995. Control of moth pests by mating disruption: successes and constraints. Annu. Rev. Entomol. 40, 559-585. https:// doi.org/10.1146/annurev.en.40.010195.003015.

Conselho Nacional do Café, 2019. Melhora nos preços pode fazer exportações de café crescerem ainda mais, dizem empresários - 
CNC - Conselho Nacional do Café. Available in: http://www.cncafe. com.br/site/interna.php?id=15126 (accessed 30 November 2020).

Consórcio de Pesquisa do Café, 2020. Exportações do café solúvel brasileiro atingem volume equivalente a 2,94 milhões de sacas de $60 \mathrm{~kg}$ em nove meses. Available in: http://www.consorciopesquisacafe. com.br/index.php/imprensa/noticias/1018-2020-08-31-16-50-20 (accessed 21 October 2020).

Costa, J. N. M., Teixeira, C. A. D., Júnior, J. R. V., Rocha, R. B., Fernandes, C. F., 2012. Informações para facilitar a identificação das diferentes fases do bicho-mineiro (Leucoptera coffeella) em campo. Embrapa Rondônia-Comunicado Técnico INFOTECA-E, Rondônia.

Dantas, J., Motta, I., Vidal, L., Bílio, J., Pupe, J. M., Veiga, A., Carvalho, C. H. S., Lopes, R. B., Rocha, T. L., Silva, L. P., Pujol-Luz, J. R., Albuquerque, É. V. S., 2020. A comprehensive review of the Coffee Leaf Miner Leucoptera Coffeella (Lepidoptera: Lyonetiidae), with special regard to neotropical impacts, pest management and control. Preprints. 2020, 2020100629. https://doi.org/10.20944/preprints202010.0629.v1

Delbac, L., Lecharpentier, P., Thiery, D., 2010. Larval instars determination for the European Grapevine Moth (Lepidoptera: Tortricidae) based on the frequency distribution of head-capsule widths. Crop Prot. 29, 623-630. https://doi.org/10.1016/j.cropro.2010.01.009.

Draganova, S. A., Tomov, R. I., 1998. Virulence of a strain Beauveria bassiana (Bals.) Vuill. (Hyphomycetes, Deuteromycotina) against larvae of Leucoptera malifoliella Costa (Lepidoptera, Lyonetiidae). Bulg. J. Agric. Sci. 4, 435-439.

Dyar, H. G., 1890. The number of molts of Lepidopterous Larvae. Psyche. 5, 420-422. https://doi.org/10.1155/1890/23871.

Ecole, C. C., Anjos, N., Michereff Filho, M. M., Picanço, M. C., 1999. Determinação do número de ínstares larvais em Plutella xylostella (L.) (Lepidoptera: yponomeutidae). Acta Sci. Biol. Sci. 21, 331-335. https://doi.org/10.4025/actascibiolsci.v21i0.4447.

Fragoso, D. B., Jusselino Filho, P., Pallini Filho, A., Badji, C. A., 2002. Acão de inseticidas organofosforados utilizados no controle de Leucoptera coffeella (Guérin-Mèneville) (Lepidoptera: Lyonetiidae) sobre o ácaro predador Iphiseiodes zuluagai Denmark \& Muma (Acari: Phytoseiidae). Neotrop. Entomol. 31, 463-467. https://doi. org/10.1590/S1519-566X2002000300018.

Guérin-Méneville, F., Perrottet, S., 1842. Mémoire sur um insect et um champignon qui ravagent les cafiers aux Antilles. Mme. Ve. Bouchard-Huzard, Imprimeur-Libraire, Paris.

Katiyar, K. P., Ferrer, F., 1968. Rearing Technique, Biology and Sterilization of the Coffee Leaf Miner, Leucoptera Coffeella Guer. (Lepidoptera: Lyonetiidae). IAEA, Vienna.

Lima, E. R., Vilela, E. F., Della Lucia, T. M. C., Ataíde, L. M. S., 2008. Age and time related pheromone production in coffee leafminer Leucoptera coffeella Guérin-Méneville (Lepidoptera: lyonetiidae). J. Braz. Chem. Soc. 19, 1659-1662. https://doi.org/10.1590/S010350532008000800030.

Magalhães, S. T. V., Fernandes, F. L., Demuner, A. J., Picanço, M. C., Guedes, R. N. C., 2010. Leaf alkaloids, phenolics, and coffee resistance to the leaf miner Leucoptera coffeella (Lepidoptera: lyonetiidae). J. Econ. Entomol. 103, 1438-1443. https://doi.org/10.1603/EC09362.

Malo, E.A., Rojas, J.C., Lopez-Guillen, G., Barrera, J.F., 2009. Chemical analysis of female volatiles and field response of the Coffee Leafminer Moth (Lepidoptera: Lyonetiidae) to stereoisomers of its major sex pheromone component. Fla. Entomol. 92, 548-553. https://doi. org/10.1653/024.092.0403

Matthews, D. L., Miller, J. Y., 2010. Notes on the Cacao Plume moth in Honduras and description of the larvae and pupae (Lepidoptera: pterophoridae). Trop. Lepid. 20, 28-34.

Medina Filho, H. P., Carvalho, A., Mônaco, L. C., 1977. Melhoramento do cafeeiro: XXXVII - observações sobre a resistência do cafeeiro ao bicho-mineiro. Bragantia 36, 131-137. https://doi.org/10.1590/ S0006-87051977000100011.

Meriño-Cabrera, Y., Zanuncio, J. C., Silva, R. S., Solis-Vargas, M., Cordeiro, G., Rainha, F. R., Campos, W. G., Picanço, M. C., Oliveira, M. G. de A., 2018. Biochemical response between insects and plants: an investigation of enzyme activity in the digestive system of Leucoptera coffeella (Lepidoptera: Lyonetiidae) and leaves of Coffea arabica (Rubiaceae) after herbivory. Ann. Appl. Biol. 172, 236-243. https:// doi.org/10.1111/aab.12416.

Mey, W., 1994. Taxonomische Bearbeitung der westpaläarktischen Arten der Gattung Leucoptera Hübner, '1825’, s. 1. (Lepidoptera, Lyonetiidae) 'Taxonomic revision of the westpalaearctic species of the genus Leucoptera Hübner, “1825”, s. I. (Lepidoptera, Lyonetiidae).'. Dtsch. Entomol.Z. 41, 173-234. https://doi.org/10.1002/mmnd.19940410119.

Michereff, M. F. F., Michereff Filho, M., Vilela, E. F., 2007. Comportamento de acasalamento do bicho-mineiro-do-cafeeiro, Leucoptera coffeella (Guérin-Mèneville) (Lepidoptera: lyonetiidae). Neotrop. Entomol. 36, 376-382. https://doi.org/10.1590/S1519-566X2007000300005.

Navarro-Gutiérrez, P., Gallardo-Covas, F., 2009. Host instar preference of Mirax Insularis (Muesebeck) (Hymenoptera: Braconidae), a Koinobiont Parasitoid of Leucoptera Coffeella Guerin-Meneville (Lepidoptera: Lyonetiidae). J. Agric. Univ. P R. 93, 139-142.

Neves, D.M.F., 2006. Análise dos benefícios econômicos e sociais da utilização do carbofurano no controle de nematoides, Bicho Mineiro (Leucoptera coffeella) e Cigarra do Cafeeiro (Quesada gigas e Fidicina pronoe) na cultura do café 29. Univ. Sao Paulo. 29.

Nielsen, E., Common, I., 1991. The Insects of Australia: A Textbook for Students and Research Workers. Melbourne University Press, Carlton.

Notley, F. B., 1948. The Leucoptera leaf miners of coffee on Kilimanjaro. 1.: Leucoptera coffeella, Guér. Bull. Entomol. Res. 39, 399-416. https:// doi.org/10.1017/S0007485300022501.

Pantoja-Gomez, L. M., Corrêa, A. S., Oliveira, L. O., Guedes, R. N. C., 2019. Common origin of Brazilian and Colombian populations of the neotropical Coffee Leaf Miner, Leucoptera coffeella (Lepidoptera: lyonetiidae).J. Econ. Entomol. 112, 924-931. https://doi.org/10.1093/ jee/toy 416.

Parra, J., Gonçalves, W., Precetti, A., 1981. Flutuação populacional de parasitos e predadores de Perileucoptera coffeella (Guérin-Méneville, 1842) em três localidades do estado de São Paulo. Turrialba 31, 357-364.

Parra, J., 1985. Biologia comparada de Perileucoptera coffeella (GuérinMèneville, 1842)(Lepidoptera, Lyonetiidae) visando ao seu zoneamento ecológico no Estado de São Paulo. Rev. Bras. Entomol. 29, 45-76.

Pereira, E. J. G., Picanço, M. C., Bacci, L., Lucia, T. M. C. D., Silva, É. M., Fernandes, F. L., 2007. Natural mortality factors of Leucoptera coffeella (Lepidoptera: Lyonetiidae) on Coffea arabica. Biocontrol Sci. Technol. 17, 441-455. https://doi.org/10.1080/09583150701309337.

Perthuis, B., Pradon, J. L., Montagnon, C., Dufour, M., Leroy, T., 2005. Stable resistance against the leaf miner Leucoptera coffeella expressed by genetically transformed Coffea canephora in a pluriannual field experiment in French Guiana. Euphytica 144, 321-329. https:// doi.org/10.1007/s10681-005-8003-9.

Ramiro, D. A., Guerreiro-Filho, O., Queiroz-Voltan, R. B., Matthiesen, S. C., 2004. Caracterização anatômica de folhas de cafeeiros resistentes e suscetíveis ao bicho-mineiro. Bragantia 63, 363-372. https://doi. org/10.1590/S0006-87052004000300006.

Reis, P., Souza, J., 1986. Pragas do Cafeeiro. In Rena, A.B. (Ed.), Cultura do Cafeeiro - fatores que afetam a produtividade. Potafós, Piracicaba.

Reis, P., Souza, J., 1996. Manejo integrado do bicho-mineiro, Perileucoptera coffeella (Guérin-Meneville) (Lepidoptera: Lyonetiidae), e seu reflexo na producao de café. 'Integrated management of the leaf 
miner, Perileucoptera coffeella (Guérin-Meneville) (Lepidoptera: Lyonetiidae).'. An. Soc. Entomol. Bras. 25, 77-82.

Schmitt, J. J., Brown, M. W., Davis, D. R., 1996. Taxonomy, Morphology, and Biology of Lyonetia prunifoliella (Lepidoptera: Lyonetiidae), a leafminer of apple. Ann. Entomol. Soc. Am. 89, 334-345. https:// doi.org/10.1093/aesa/89.3.334.

Seven, S., 2006. Lyonetiidae of Turkey with notes on their distribution and zoogeography (Lepidoptera). Zootaxa 1245, 53-58. https://doi. org/10.11646/zootaxa.1245.1.2.

Solis, M. A., Metz, M. A., 2016. An illustrated guide to the identification of the known species of Diatraea Guilding (Lepidoptera, Crambidae, Crambinae) based on genitalia. ZooKeys 565, 73-121. https://doi. org/10.3897/zookeys.565.6797.

Vieira, L.G.E., Andrade, A.C., Colombo, C.A., Moraes, A.H. de A., Metha, Â., Oliveira, A.C., Labate, C.A., Marino, C.L., Monteiro-Vitorello, C.B., Monte, D.C., Giglioti, É., Kimura, E.T., Romano, E., Kuramae, E.E., Lemos, E.G.M., Almeida, E.R.P., Jorge, É.C., Albuquerque, É.V.S., Silva, F.R., Vinecky, F., Sawazaki, H.E., Dorry, H.F.A., Carrer, H., Abreu, I.N., Batista, J.A.N., Teixeira, J.B., Kitajima, J.P., Xavier, K.G., Lima,
L.M., Camargo, L.E.A., Pereira, L.F.P., Coutinho, L.L., Lemos, M.V.F., Romano, M.R., Machado, M.A., Costa, M.M.C., Sá, M.F.G., Goldman, M.H.S., Ferro, M.I.T., Tinoco, M.L.P., Oliveira, M.C., Van Sluys, M., Shimizu, M.M., Maluf, M.P., Eira, M.T.S., Guerreiro Filho, O., Arruda, P., Mazzafera, P., Mariani, P.D.S.C., Oliveira, R.L.B.C., Harakava, R., Balbao, S.F., Tsai, S.M., Mauro, S.M.Z., Santos, S.N., Siqueira, W.J., Costa, G.G.L., Formighieri, E.F., Carazzolle, M.F., Pereira, G.A.G., 2006. Brazilian coffee genome project: an EST-based genomic resource. Braz. J. Plant Physiol. 18, 95-108. https://doi.org/10.1590/S167704202006000100008.

Wheatley, P. E., Crowe, T. J., 1964. Field studies of insecticides against the coffee leaf-miner Leucoptera meyricki Ghesq. (Lepidoptera, Lyonetiidae). Bull. Entomol. Res. 55, 193-203. https://doi.org/10.1017/ S0007485300049397.

Wolcott, G., 1947. A quintessence of sensitivity: the coffee leaf-miner. J. Agric. Univ. P R. 31, 215-219.

Zhang, Z. 2011. Animal biodiversity: an outline of higher-level classification and survey of taxonomic richness. Zootaxa. 3703, 1-82. 